\title{
Aligning Information Technology Within The Framework Of Corporate Governance To Increase Corporate Value In Mexico
}

\author{
Carlos Fernando Estrada, Anáhuac University, Mexico
}

\begin{abstract}
This research focuses on the potential benefits of aligning corporate Information Technologies (IT) with the information needs of Board members to provide pertinent and timely information under good Corporate Governance (CG) practices. The recent near collapse of some major corporations evidences poor regulatory supervision by all parties, both public and private. An abundance of regulations notwithstanding, stakeholder interests (both internal and external) have not been protected or served by many corporate boards. Many shareholders have virtually lost their capital, workers have been unemployed, and government and taxpayers have had to foot steep bills. Well informed Board members should, in theory, make decisions that benefit their stakeholders and society as well. Thus, corporate board members should focus on IT as a key resource and ally in monitoring their business strategies and operations. IT permeates throughout business processes and across functional areas in most businesses, so if IT reporting is aligned with corporate governance objectives as well as operational objectives, it has the potential to aid greatly in governance. An important consideration of course, is what information is provide, and how the Board utilizes it for the stakeholders' benefit.
\end{abstract}

Keywords: information technology, corporate governance, Mexico

\section{INTRODUCTION}

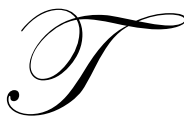

he paper highlights the importance for corporations to have a board with sufficient IT proficiency to capitalize on the benefits of presently available technologies, rather than discharging all IT reporting (together with the implicit strategy implications) onto the CEO and operational management. IT management has evolved to now include IT Governance (ITG). The focus of this research is principally on IT's role and utility for corporate governance, but it also includes ITG insofar as it may be part of corporate governance. There are important duties between IT and corporate governance that overlap.

Porter1 states that a firm implies a great number of technologies with different relevancies and weights for the final product at every stage in an organization's value chain. Information technology particularly permeates the value chain since every stage creates and uses information from production, logistics, sales, performance metrics, as well as their interrelationships.

Research has shown that companies with formal corporate governance can achieve greater profits than competitors with similar business strategies ${ }^{2}$. There are indications that institutional investors pay premiums of up to $30 \%$ for stocks of companies applying Corporate Governance practices ${ }^{3}$.

1Competitive Advantage, Michael Porter, 1987

2Weill \& Ross, HBR 2004

3McKinsey \& Co. Survey 2000 
- A recent study on Corporate Governance in 14 emerging markets, found wide variations in investor protection and performance ${ }^{4}$ among companies with different levels of governance. Generally, organizations' corporate governance was proportionally as strong or weak as their country's legal system. A clear relation was found with their asymmetric information. Likewise, corporate governance correlates highly with best performance practices and market valuation.

- $\quad$ Key corporate performance metrics are an important management tool, and should include metrics related to IT, like the return on IT investments since they are frequently large, and may not always be justifiable, depending on types of projects involved in operational IT value, many metrics available and the challenge is define by those needed for a particular IT investment.

- Current research is highlighting the capacity of managers to utilize legal and financial maneuvers that can adversely affect investors' interests. Such actions can be mitigated by well conceived legal systems, such as exist in Delaware, that contemplate different proprietary structures, dividend payments, availability and external financial costs, as well as market valuation ${ }^{5}$, among other aspects. board needs.

The challenge is to adapt and apply the science of metrics to the task of providing information for corporate

\section{THE PROBLEM}

Organizational governance at the board level frequently lacks the financial and technical resources to tailor performance metrics using IT resources. Boards are therefore handicapped from deriving the full benefit of corporate IT investments. Corporate governance also generally lacks effective Information Technology governance as a tool to increase corporate profitability though the application of IT performance metrics. It is imperative to bring together and to align corporate governance and IT governance and to look for synergies between the two. Understanding the different roles of informational technologies available among organizations, within processes and in the way IT works, can assist in regards to regulatory compliance, cost containment, and creating long term value.

\section{Key Research Questions} following.

Four main aspects of corporate board's relationship with IT were included in this research, including the

- $\quad$ Are board members adequately IT literate to evaluate the returns from IT investments?

- Why have boards and board members to date been unable or uncommitted to evaluating and reporting on IT risk management alongside normal control and transparency reporting of the organization's resources to regulatory authorities and owners?

- Are boards aware of the potential benefits of applying information technologies to create value for investors?

- $\quad$ Are boards doing an adequate job of supervising the alignment of the organization's IT with its strategy?

\section{GENERAL THEORETICAL FRAMEWORK}

The research focuses on Corporate Governance management, impelled initially by the OCED and on the Information Technologies that provide key performance information to corporate boards, particularly deriving from two bodies of work:

- $\quad$ Corporate Governance Theory, ${ }^{5}$ and

- The theory of the Information Technology Governance ${ }^{6}$.

4Leora F. Klapper \& Inessa Love from World Bank 2003

5Developed by the International Finance Corporation from the World Bank, Global Corporate Governance Forum and Cadbury, Greenbury \& Hampel from the United Kingdom, beginning in 1991.

6 Weill, P.; Westerman G.; and Ross, J. Sloan School of Management and Center for Information Systems at MIT, and Robertson, 
The Corporate Governance responsibility of a board is to act as a counterpart and guide to management, guaranteeing its quality, opportunity and the adequate dissemination of financial and operational information. Corporate governance includes processes, authorities, policies, laws and institutions that affect the way an organization is managed or controlled. It also includes the relations among other groups, such as: shareholders, management team and the Board, as well as employees, suppliers, customers, banks and other creditors, regulatory authorities $^{7}$, the environment and the community in whole. It is a task with multiple planes of contact, extending from legal responsibility, fiduciary duties, providing accurate information to shareholders and stakeholders in general, responsibility for audits and control mechanisms, and including social responsibility.

This research required an interdisciplinary approach on legal, economic issues, with a strong understanding of modern management practices including those coming from empirical studies ${ }^{8}$.

\section{Referable Theoretical Framework}

As businesses attempt to create value out of IT, management and the board should be aware that IT's objectives, decisions and behavior need to be aligned with the organization's objectives. Thus, on an ongoing basis, members of the organization make decisions that influence the IT value received. IT decisions should therefore best be designed with a comprehensive and integrative focus, not in isolation, and should include relevant committees' decisions. Firms with an integrated IT structure appear to obtain significantly greater profits, up to $20 \%$, than those firms with similar business strategies, but without an integrated IT structure. One possible explanation is that some firms align their IT investments with the business's priorities while others make case by case investments, often as a result of current modes and trends, and without well thought out IT strategies that are aligned with the business' overall strategy. ${ }^{9}$

Survey results showed that $38 \%$ of high level managers acknowledge the benefits of IT governance practices ${ }^{10}$. Thus it appears that spending time to design, practice and adequately communicate ITG processes are worth the effort and time consumed. One way to illustrate the issue is when corporate information officers are required to cut expenses, they may respond by reducing services, causing their internal customers reduces expenses, and his internal clients are satisfied because they contracted those services externally. Sometimes it can be appropriate, though in other circumstances profits may be sub optimized.

There is research evidence about firms that assign direct responsibility to their board for IT investment decisions to ensure that IT aspects are incorporated in the strategic decision process. In this way the CIO, who is part of the top management team, can translate decision and investment principles into IT standards. Business unit projects are then more likely to be designed in the context of the whole business so that IT decisions have a dual objective of improving both the business unit's performance, and of supporting Corporate Governance tasks. Firms can create value by analyzing their processes and different business units, using a segmented analysis of their components. ${ }^{11}$.

D., Harvard Business School and Kennedy School of Government at Harvard University.

7 Bebchuk \& Roe, “A Theory of Path Dependence in Corporate Ownership and Governance” in Gordon \& Roe 69-113. Bebchuk, "The Debate on Contractual Freedom in Corporate Law" 89 Colum. L.J. 1395-1399 y 1404-1415 (1989), transplants of Corporate Governance.

8 Deakin, S. \& Monks, R.

9 "Design and communication of ITG" Based on a survey of best business practices applied to 300 firms in 23 countries by Weill \& Ross from MIT, 2002.

10 McKinsey \& Co. Survey 2000.

11 "Value Creation" Ph D Patrick Leemputte \& Ph D Mary Kearney, from Price Waterhouse in 1996. 


\section{RESEARCH APPROACH}

Two types of research were employed in this investigation:

- $\quad$ Mixed Approach Explicative - Causal: This part of the work focused on the analysis of qualitative \& quantitative aspects of the incidence among corporate boards that align IT governance and corporate governance practices to create value.

- Explicative - Causal: Here we attempt to explain relationships among independent variables " $x$ " (level/degree of alignment between IT governance practices and corporate governance practices), and dependent variables " $y$ " value creation (or higher efficiency in relevant and selected management metrics).

\section{SCOPE}

Universe

The research universe encompasses medium and large Mexican firms, both those listed on the Mexican stock exchange, as well as unlisted firms.

\section{Limits}

The research is limited to firms suitable to the research, the availability of resources, and firms with formal IT and Corporate Governance practices ${ }^{12}$. The research itself also relies on the formality and degree that IT Governance practices were incorporated to support corporate governance priorities.

\section{HYPOTHESIS}

\section{Main Hypothesis}

Firms applying an information technology structure within the framework of corporate governance will improve their performance metrics. There is an important relation between IT applications and incremental profits as a result of more structured information.

\section{Working Hypothesis}

- There is a significant benefits relationship between aligning business strategy and information technology benefits. The Board must play a relevant role in decision making to ensure value creation based on IT both to minimize risks and to create value.

\section{RESEARCH DESIGN}

\section{Research Process}

- A quasi-experimental design was posited. Companies included in the analysis were to have adopted IT schemes within the structure of corporate governance and to have measured the incidence of quantifiable benefits.

- $\quad$ The research was designed to identify and demonstrate the interaction of IT's role in increasing profits among other relevant metrics.

12 LaPorta et al. "Investor Protection and Corporate Governance," (with F. López-de- Silanes, A. Shleifer and R. Vishny), Journal of Financial Economics, October 2000 


\section{Field Research}

- Originally the research was to be quasi-experimental, examining case histories of various companies about to apply ITG and CG. In practice, it was not possible to apply an Experimental approach, since none of the companies decided to implement ITG and CG within the time frame. The focus was re-directed to companies that had already implemented ITG/CG schemes in their corporate structures. The research analyzed the selected metrics of those companies. Several firms in specific industry segments were included to permit better comparisons and explanations about the impact of IT governance on corporate governance.

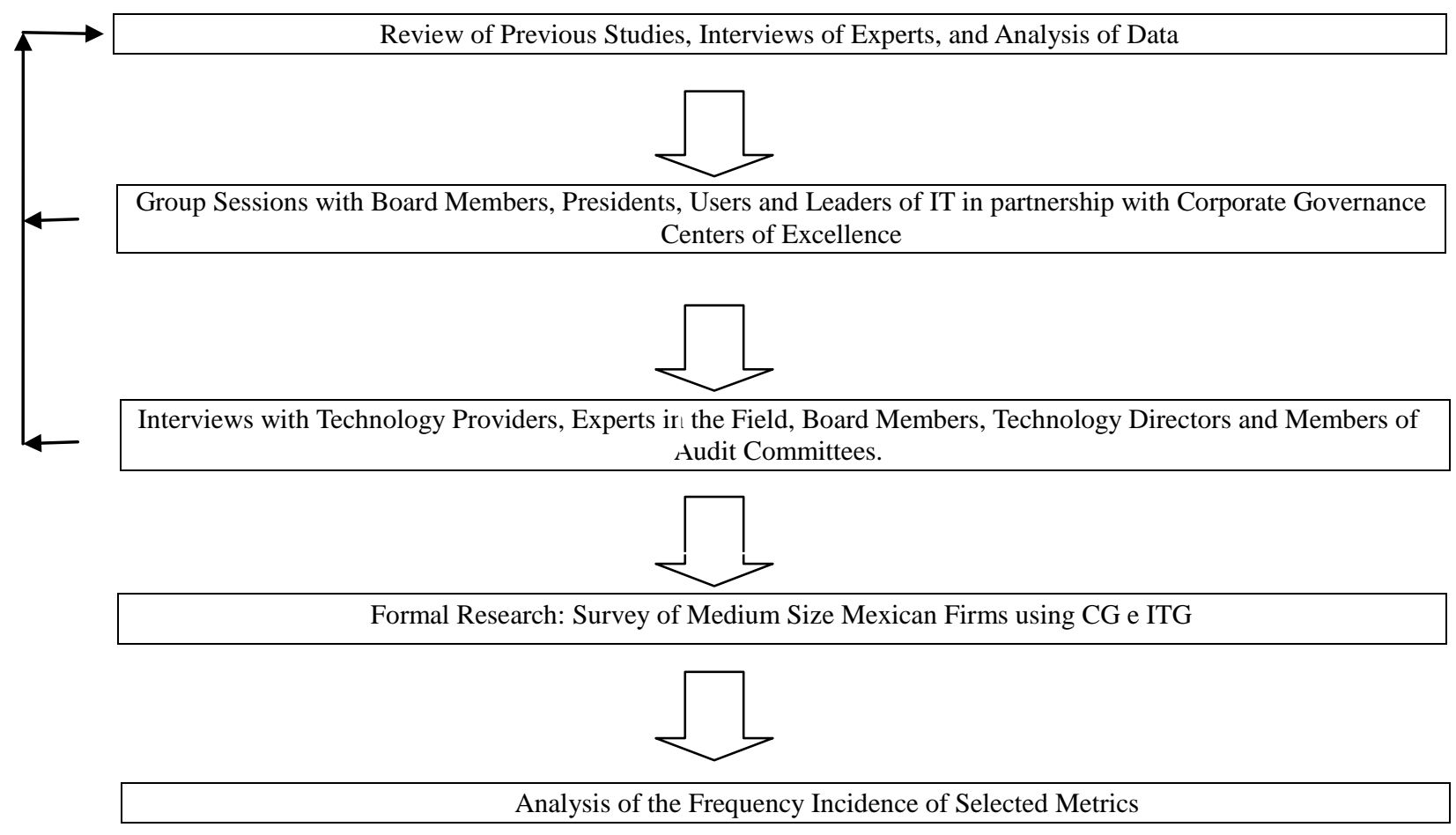

\section{EXPECTED RESULTS}

- Measure the positive impact on organizations incorporating aligned ITG and CG practices to enhance Board contributions to corporate results 13 .

- Validate the paradigm that firms adopting corporate governance practices supported by IT governance do create value for the organization.

- $\quad$ Contribute to Corporate Governance theory regarding the incidence of IT performance metrics and practices.

- $\quad$ Disseminate the best practices and metrics to contribute to the greater effectiveness of Board members.

- $\quad$ Suggest opportunities to enrich MIS theory with IT governance to improve Board performance and organization performance.

13 Njoya, "Employee Ownership and Efficiency: An Evolutionary Perspective" 33 Indus. L.J. 211 (2004) 


\section{WORK PLAN (SEMESTER)}

\begin{tabular}{|c|c|c|c|c|c|}
\hline Activity & $\begin{array}{l}2006 \\
1 \quad 2\end{array}$ & $\begin{array}{l}2007 \\
122\end{array}$ & $\begin{array}{l}2008 \\
1 \quad 2\end{array}$ & $\begin{array}{l}2009 \\
1 \quad 2\end{array}$ & $\begin{array}{l}2010 \\
12\end{array}$ \\
\hline Idea Conceived & $\mathrm{x}$ & & & & \\
\hline Problem Stated & $\mathrm{x}$ & & & & \\
\hline Literature Review & $\mathrm{x}$ & & & & \\
\hline Research Scope & & $\mathrm{x}$ & & & \\
\hline Hypothesis & $\mathrm{x}$ & $\mathrm{x}$ & & & \\
\hline Design & & $\mathrm{x} x$ & & & \\
\hline Sample selection & & $\mathrm{x} x$ & & & \\
\hline Data gathering & & & $\mathrm{x} x$ & & \\
\hline Analysis & & & $\mathrm{x}$ & $\mathrm{x} \quad \mathrm{x}$ & \\
\hline Report & & & & & $\mathrm{x}$ \\
\hline
\end{tabular}

\section{AUTHOR INFORMATION}

Carlos Fernando Estrada is currently completing his doctor of philosophy degree at Anáhuac University in Mexico. The author's research was directed by Ph.D. Carlos Barber Kuri and Ph.D. Raul Mejia Estanol.

\section{REFERENCES}

1. Barber Kuri, C.M. (2005). "Megatendencias". Integra Business Review. No. 6. Universidad Anáhuac del Sur. México.

2. Barber Kuri, C.M. (2005).“Industrias representativas de América, Europa y Asia”. EdM. Porrúa Mx

3. Barber Kuri, C.M. (2005). "Casos empresariales”. Tomo II. Miguel Angel Porrúa-UAS. México.

4. IFC (2004) Presented by Mike Lubrano, Corporate Governance Director at IFC.

5. Jones, G.R. and George, J.M., Contemporary Management. $4^{\text {th }}$ Ed., (McGraw-Hill, 2005).

6. Kaplan, R. and Norton, D. "The Balance Scorecard: Translating Strategies into Action" (2002).

7. La Porta, R., Lopez-de-Silanes, F., Shleifer, A., and Vishny, R.W., 2000. Investor protection and corporate governance. Journal of Financial Economics 58 (1), 3-27.

8. Porter, M.E. 1985. Competitive advantage: Creating and sustaining superior performance. NY Free Press.

9. Corporate governance, investor protection, and performance in emerging markets. Klapper, L. and Love, I. The World Bank, 1818 H Street, NW, Washington, DC 20433, USA. 4 February 2003.

10. Weill, P. and J.W. Ross (2004) IT governance: How Top Performers Manage IT Decision Rights for Superior Results, Watertown, MA: Harvard Business School Press.

11. Weill, P. and J.W. Ross (2005) "A Matrixed Approach to Designing IT Governance", Management Review (46)2, pp. 26-34.

12. Kaplan R S and Norton D P (1992) "The balanced scorecard: measures that drive performance", Harvard Business Review Jan - Feb pp71-80. Kaplan R S and Norton D P (1993) "Putting the Balanced Scorecard to Work", Harvard Business Review Sep - Oct pp2-16.

13. Cadbury, A. (1992), "Report of the Committee on the Financial Aspects of Corporate Governance", London: Gee and Company Ltd.

14. Porter, M. (1980). "Competitive Strategy", New York: Free Press

15. Weill, P. and Broadbent, M. (2003), "Creating Effective IT Governance, a Gartner EXP Premier Research Report." Stamford, CT: Gartner. 